\title{
Reactions of Nicotiana species to inoculation with monopartite and bipartite begomoviruses
}

\author{
Sohail Akhtar, Rob W Briddon and Shahid Mansoor
}

\begin{abstract}
Background: Some Nicotiana species are widely used as experimental hosts for plant viruses. Nicotiana species differ in ploidy levels, chromosome numbers and have diverse geographical origins. Thus, these species are useful model systems to investigate virus-host interactions, co-evolution of pathogens and hosts and the effects of ploidy level on virus resistance/susceptibility.

Results: Here we have studied the responses of seven Nicotiana species to inoculation with Cotton leaf curl Multan virus (CLCUMV), a monopartite begomovirus, and Tomato leaf curl New Delhi virus (ToLCNDV), a bipartite begomovirus, both from the Indian subcontinent. All Nicotiana species supported the replication of both begomoviruses in inoculated leaves. However, only three Nicotiana species, namely N. benthamiana, N. tabacum and $N$. sylvestris showed symptoms when inoculated with ToLCNDV, while $N$. benthamiana was the only species that developed leaf curl symptoms when inoculated with CLCUMV. CLCUMV accumulated to detectable levels in $N$. tabacum, but plants remained asymptomatic. A previously identified mutation of RNA dependent RNA polymerase 1 was shown to be present only in $N$. benthamiana. The finding is in line with earlier results showing that the susceptibility of this species to a diverse range of plant viruses correlates with a defective RNA silencing-mediated host defense.

Conclusions: The results presented show that individual Nicotiana species respond differently to inoculation with begomoviruses. The inability of begomoviruses to systemically infect several Nicotiana species is likely due to inhibition of virus movement, rather than replication, and thus provides a novel model to study virus-host interactions in resistant/susceptible hosts.
\end{abstract}

\section{Background}

The genus Nicotiana (family Solanaceae) comprises 77 species, of which 40 are diploid and 37 allopolyploids. Named after the French ambassador to Portugal, Jean Nicot, who introduced tobacco to France in 1559, it is believed to have evolved in South America and then dispersed to Australia, Africa and southwestern North America [1]. The genus has been the focus of intense study which has provided information concerning the evolutionary relationships among different species found in this genus. Notably, Nicotiana benthamiana and $N$. tabacum (both allotetraploid) have become species used extensively in cytogenetic and plant virology studies [2].

Geminiviruses are single-stranded (ss)DNA viruses with circular genomes and are classified into four

\footnotetext{
* Correspondence: shahidmansoor7@gmail.com

Agricultural Biotechnology Division, National Institute for Biotechnology and Genetic Engineering, Faisalabad, Pakistan
}

genera based on host range, insect vector and genome organization [3]. They are widely distributed throughout the world and infect either monocotyledonous or dicotyledonous hosts. All geminiviruses that infect monocotyledonous plants belong to the genus Mastrevirus, have genomes consisting of a single component and are transmitted by leafhoppers. A small number of dicotinfecting mastreviruses have also been identified. Viruses of the genus Curtovirus have single component genomes and are transmitted by leafhoppers. The genus Topocuvirus encompasses a single species with a genome consisting of a single component and is transmitted by treehopper. Viruses of the genus Begomovirus are transmitted by a single species of whitefly, Bemisia tabaci, and have genomes that consist of either a single ssDNA or two ssDNA components. The two components of bipartite begomoviruses are referred to as DNA A and DNA B, and both are, for most species, 
essential for symptomatic infection of plants. Monopartite begomoviruses are often associated with DNA satellites known as alphasatellites and betasatellites [4]. These begomovirus disease complexes are widespread in the Old World and constitute the largest group of begomoviruses. Studies on begomoviruses and their associated satellites suggest that they co-evolved with their hosts [5].

RNA silencing is an antiviral defense mechanism of plants that is induced by the replication of viruses and formation of viral double-stranded (ds)RNAs. These dsRNAs are the precursors of small interfering (si) RNAs that are involved in RNA silencing pathways [6-8]. Plant viruses counteract these defenses by encoding suppressors of gene silencing. Depending on the virus, individual viral proteins with differing primary functions in viral infection act as suppressors, interfering with distinct steps of the silencing pathway [9]. Various proteins encoded by begomoviruses and their satellites have been reported as suppressors of gene silencing; such as $\beta \mathrm{C} 1$ encoded by the betasatellite, which is the major symptom determinant encoded by begomovirus disease complexes [10,11]. Suppressors of RNA silencing encoded by viruses may influence micro (mi)RNA levels and thus may be responsible for the symptoms induced by infection. miRNAs are involved in the control of gene expression during growth and development of plants [12].

The study reported here has analysed the infectivity of monopartite and bipartite begomoviruses to various diploid and tetraploid Nicotiana species so as to assess the effects of ploidy level on susceptibility to begomoviruses. Local as well as systemic infection was determined by using PCR and Southern hybridization techniques. We tried to observe the presence of RDR1m in all the species and especially in those which are susceptible to viruses used in experiments. We also tried to link the origin of species and evolution of geminiviruses in different geographical locations.

\section{Results}

Infectivity of Cotton leaf curl Multan virus to Nicotiana species

To assess the ability of begomoviruses to replicate and move systemically from site of inoculation, infectious clones of representative monopartite and bipartite begomoviruses were introduced into plants by agroinfiltration $[13,14]$. Inoculation with the monopartite begomovirus Cotton leaf curl Multan virus (CLCuMV) led to characteristic leaf curl symptoms only in $N$. benthamiana plants at 25 days post-inoculation (Table 1). Plants of all the other species investigated remained symptomless (Figure 1; Table 1, 2). Total genomic DNA was extracted from inoculated leaves, as well as leaves developing subsequent to inoculation, for PCR and Southern hybridization to assess virus replication and movement. PCR results showed that in $N$. benthamiana and N. tabacum CLCuMV was able to spread from the site of inoculation (Figure 2). A very low-level amplification in case of $N$. nudicaulis indicated poor movement of the virus in this species. For the remaining Nicotiana species no viral DNA was detected by PCR in upper

Table 1 Summary of the results of the infectivity studies

\begin{tabular}{|c|c|c|c|c|c|c|c|}
\hline $\begin{array}{l}\text { Species } \\
\text { (ploidy level, } \\
\text { chromosome } \\
\text { number) }\end{array}$ & Parents & Origin & $\begin{array}{l}\text { Infectivity of } \\
\text { ToLCNDV } \\
\text { (plants } \\
\text { symptomatic/ } \\
\text { plants } \\
\text { inoculated) }\end{array}$ & $\begin{array}{l}\text { Plants PCR } \\
\text { positive for } \\
\text { ToLCNDV with } \\
\text { primers } \\
\text { ToLCNDVV2F/ } \\
\text { ToLCNDVV2R }\end{array}$ & $\begin{array}{l}\text { Infectivity of } \\
\text { CLCuMV } \\
\text { (plants } \\
\text { symptomatic/ } \\
\text { plants } \\
\text { inoculated) }\end{array}$ & $\begin{array}{l}\text { Plants PCR } \\
\text { positive for } \\
\text { CLCuMV with } \\
\text { primers } \\
\text { PK3AV2F/ } \\
\text { PK3AV2R }\end{array}$ & $\begin{array}{l}\text { Plants PCR } \\
\text { positive for } \\
\text { CLCuMV with } \\
\text { primers } \\
\text { BegomoF/ } \\
\text { BegomoR }\end{array}$ \\
\hline $\begin{array}{l}\text { N. sylvestris } \\
(2 x=24)\end{array}$ & - & $\begin{array}{l}\text { South } \\
\text { America }\end{array}$ & $4 / 4$ & 4 & $0 / 4$ & 0 & $0(0.7)^{*}$ \\
\hline $\begin{array}{l}\text { N. obtusifolia } \\
(2 x=24)\end{array}$ & - & $\begin{array}{l}\text { Southwestern } \\
\text { USA, Mexico }\end{array}$ & $0 / 4$ & 0 & $0 / 4$ & 0 & $0(1.4)^{*}$ \\
\hline $\begin{array}{l}N . \\
\text { benthamiana } \\
(4 \mathrm{x}=38)\end{array}$ & $\begin{array}{l}\text { N. sylvestris } \\
\text { (likely maternal } \\
\text { parent) }\end{array}$ & Australia & $4 / 4$ & 4 & $4 / 4$ & 4 & $4(2.8)^{*}$ \\
\hline $\begin{array}{l}\text { N. suaveolens } \\
(4 x=32)\end{array}$ & $\begin{array}{l}\text { N. sylvestris } \\
\text { (likely maternal } \\
\text { parent) }\end{array}$ & Australia & $0 / 4$ & 0 & $0 / 4$ & 0 & 0 \\
\hline $\begin{array}{l}\text { N. tabacum } \\
(4 x=48)\end{array}$ & $\begin{array}{l}\text { N. } \\
\text { tomentosiformis, } \\
\text { N. sylvestris }\end{array}$ & $\begin{array}{l}\text { Eastern North } \\
\text { America }\end{array}$ & $4 / 4$ & 4 & $0 / 4$ & 4 & $4(2.8)^{*}$ \\
\hline $\begin{array}{l}\text { N. nudicaulis } \\
(4 x=48)\end{array}$ & $\begin{array}{l}\text { N. obtusifolia, } N \text {. } \\
\text { sylvestris }\end{array}$ & $\begin{array}{l}\text { North } \\
\text { America }\end{array}$ & $0 / 4$ & 4 & $0 / 4$ & 2 & $2(2.8)^{*}$ \\
\hline $\begin{array}{l}\text { N. repanda } \\
(4 \mathrm{x}=48)\end{array}$ & $\begin{array}{l}\text { N. obtusifolia, } N \text {. } \\
\text { sylvestris }\end{array}$ & $\begin{array}{l}\text { Southern } \\
\text { Texas (USA) }\end{array}$ & $0 / 4$ & 4 & $0 / 4$ & 0 & $0(1.4)^{*}$ \\
\hline
\end{tabular}

*The sizes of bands produced in PCR reactions with primers BegomoF/BegomoR are shown in kb. The expected size product is $2.8 \mathrm{~kb}$ for a full CLCuMV genome. 

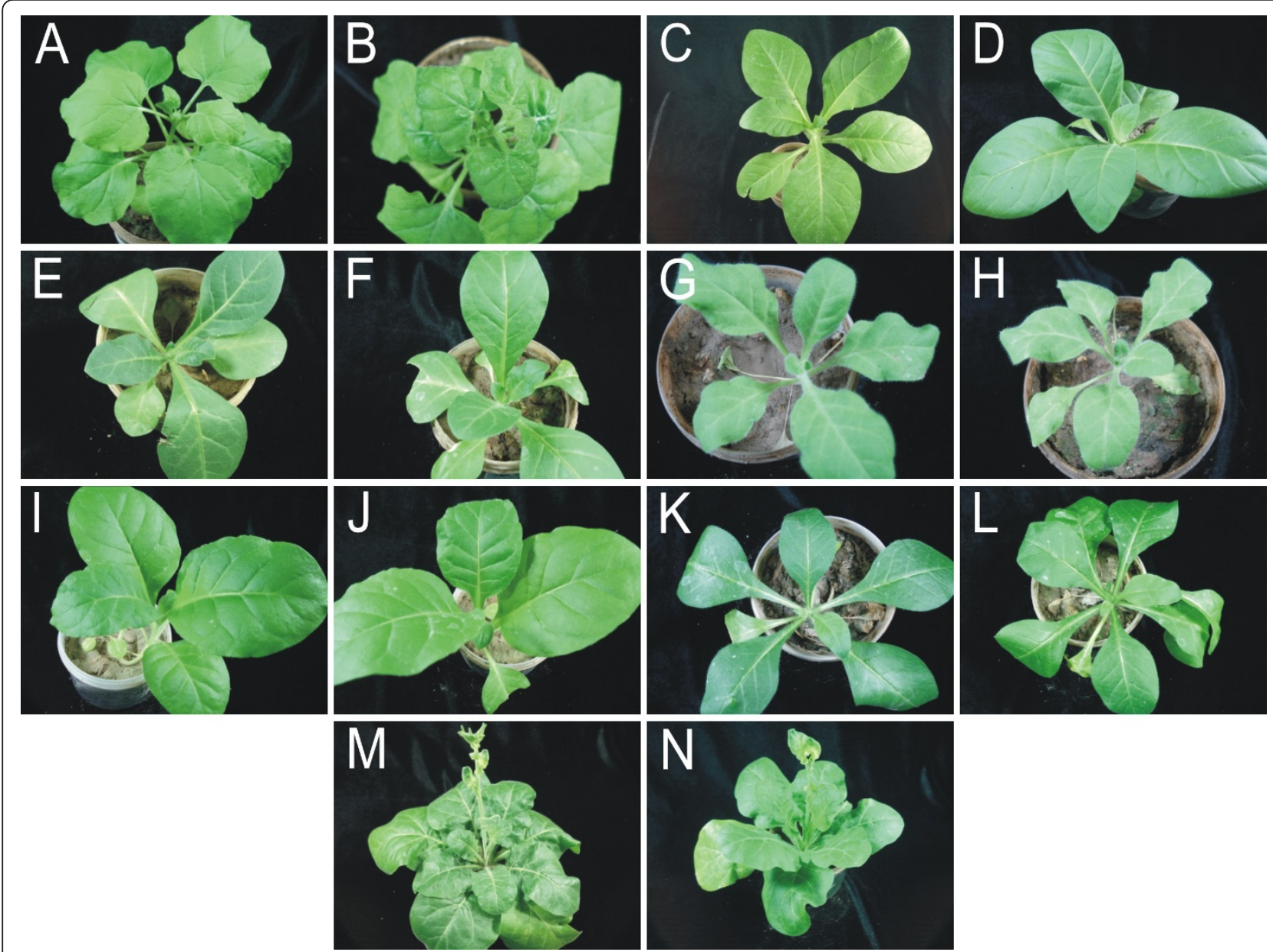

Figure 1 Photographs of Nicotiana species at 25 days after inoculation with CLCuMV. Shown are photographs of non-inoculated $\mathrm{N}$. benthamiana (A), N. sylvestris (C), N. nudicaulis (E), N. obtusifolia (G), N. tabacum (I), N. suaveolens (K) and N. repanda (M) plants and photographs of N. benthamiana (B), N. sylvestris (D), N. nudicaulis (F), N. obtusifolia (H), N. tabacum (J), N. suaveolens (L) and N. repanda (N) plants inoculated with CLCUMV.

Table 2 Summary of Southern hybridization results for the detection of CLCuMV and ToLCNDV in inoculated Nicotiana plants

\begin{tabular}{|c|c|c|c|}
\hline \multirow[t]{2}{*}{ Nicotiana species } & \multicolumn{2}{|c|}{ CLCuMV } & \multirow{2}{*}{$\begin{array}{c}\text { ToLCNDV } \\
\text { Movement* }\end{array}$} \\
\hline & Replication $^{\#}$ & Movement $^{*}$ & \\
\hline N. benthamiana & + & + & + \\
\hline N. tabacum & + & + & + \\
\hline N. sylvestris & + & - & + \\
\hline N. obtusifolia & + & - & - \\
\hline N. nudicaulis & + & - & + \\
\hline N. suaveolens & + & - & - \\
\hline N. repanda & + & - & - \\
\hline
\end{tabular}

Hybridization is indicated as either positive $(+)$, indicating the presence of bands hybridizing to the probe, or negative (-), no bands hybridizing to the probe.

*Detection of hybridizing bands in DNA extracted from leaves developing at the time of, or subsequent to, inoculation.

"Detection of hybridizing bands in inoculated leaves. leaves, indicative of a lack of virus movement from the site of inoculation (Figure 2). A Southern blot of DNA extracted from leaves developing subsequent to inoculation probed for the presence of viral DNA showed a high virus titre in N. benthamiana and N. tabacum (Figure 3; Table 2). However, for N. nudicaulis, which was virus positive by PCR, no viral DNA was detected in the upper leaves. This suggests that virus levels in N. nudicaulis were very low, below the detection threshold of Southern hybridization

PCR mediated amplification with primers designed to amplify the whole CLCuMV genome (BegomoF/BegomoR) showed the presence of full-length viral genomic DNA in N. benthamiana, $N$. tabacum and $N$. nudicaulis (Figure 4). Additionally, less than full-length, subgenomic molecules were detected in $N$. benthamiana, $N$. sylvestris, $N$. obtusifolia and $N$. repanda. 


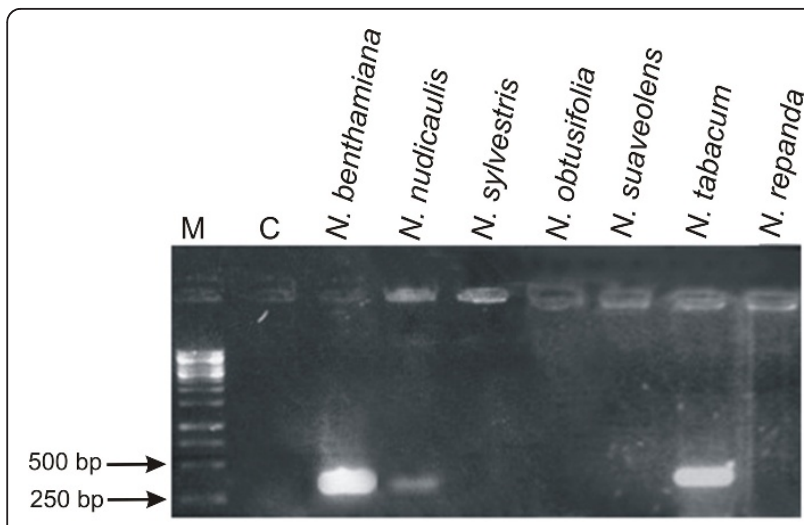

Figure 2 PCR-mediated detection of CLCUMV in inoculated Nicotiana plants. The ethidium bromide-stained agarose gel was photographed under UV illumination. The samples loaded on the gel resulted from PCR reactions with primer pair PK3AV2F/PK3AV2R and DNA extracted from the leaves of plants (as indicated above each well) inoculated with CLCuMV. The leaves sampled were developing at the time of, or developed after, inoculation and were sampled at $25 \mathrm{dpi}$. The presence of a $311 \mathrm{bp}$ band indicates the systemic movement of CLCUMV from the site of inoculation. The sample in lane $C$ resulted from PCR amplification with DNA extracted from a healthy $N$. benthamiana plant. A DNA size marker was electrophoresed in lane M. The sizes (bp) of selected marker bands are indicated on the left.

Southern blot analysis of DNA extracted from inoculated leaves showed that there was efficient virus DNA replication in all Nicotiana species. The amount of single-stranded DNA was highest in N. benthamiana and lowest in N. suaveolens and N. obtusifolia. Several species that did not show systemic symptoms or movement accumulated higher levels of the linear form of viral DNA (Figure 5). This indicates that the lack of symptoms in all Nicotiana spp., except $N$. benthamiana, was due to a lack of (efficient) virus movement from the site of inoculation, rather than a lack of viral DNA replication. However, for $N$. tabacum, this was not the case with both virus replication and movement occurring without producing symptoms. Additionally, the Southern blot showed the presence of sub-genomic (defective) viral DNA forms in both $N$. benthamiana and $N$. tabacum.

\section{Infectivity of Tomato leaf curl New Delhi virus to Nicotiana species}

Inoculation of Nicotiana species with Tomato leaf curl New Delhi virus (ToLCNDV) induced leaf curling and stunting symptoms in $N$. benthamiana, $N$. tabacum and N. sylvestris at three weeks post inoculation (Figure 6; Table 1). PCR-mediated detection of the virus with primers ToLCNDV2F/ToLCNDV2R in upper, non-inoculated leaves showed the presence of viral DNA in all Nicotiana spp. except $N$. obtusifolia and $N$. suaveolens

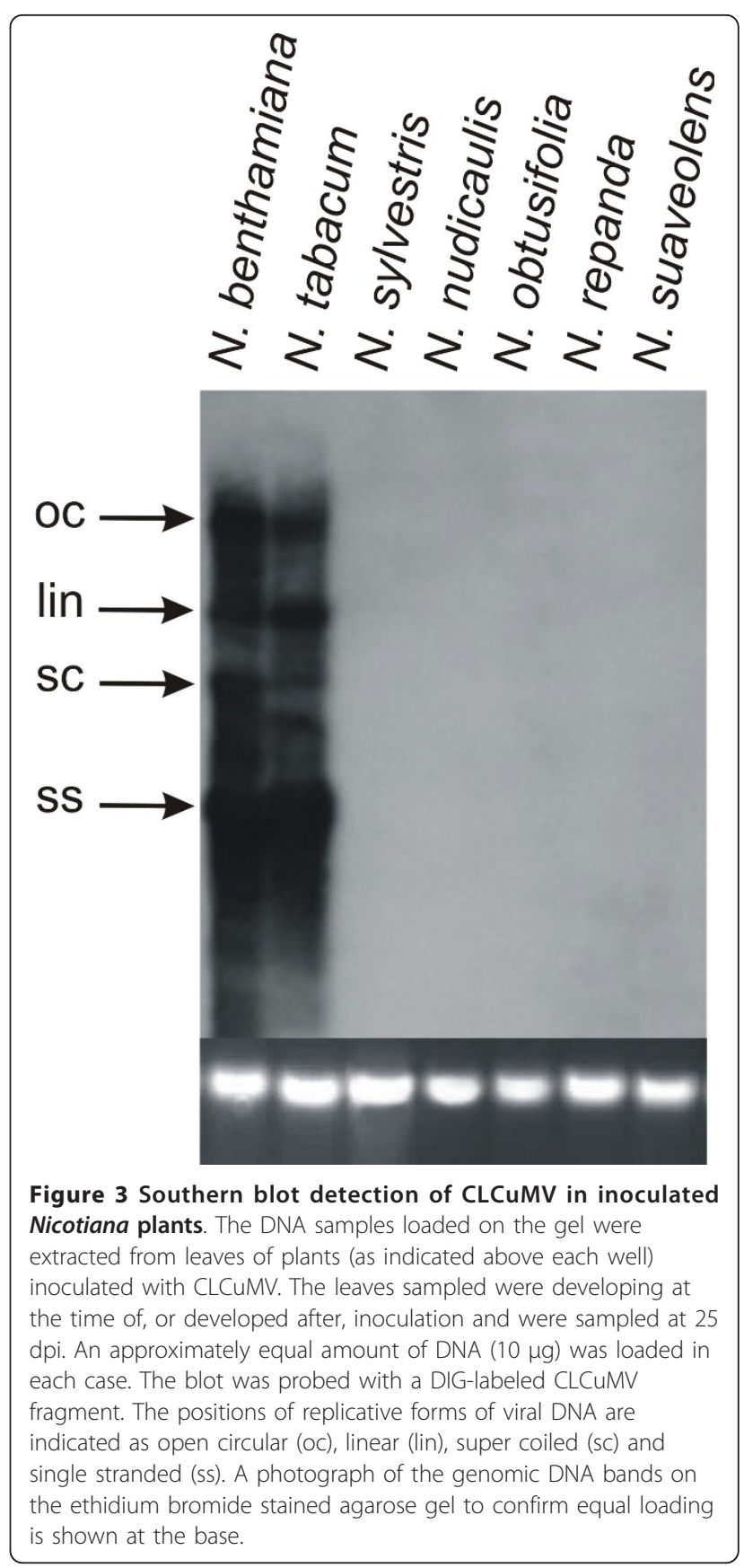

(Figure 7). A slightly lower level of amplification product was detected in $N$. repanda than the other species, suggesting that the virus titre in this species may be lower.

Southern blot analysis showed high virus DNA levels in $N$. benthamiana, $N$. nudicaulis, $N$. sylvestris and $N$. tabacum (Figure 8). For N. repanda only low levels of viral DNA was detected which consisted almost entirely of ssDNA. No hybridizing bands were detected for $N$. obtusifolia and N. suaveolens, indicating that ToLCNDV was not able to spread from the site of inoculation (Table 2). 


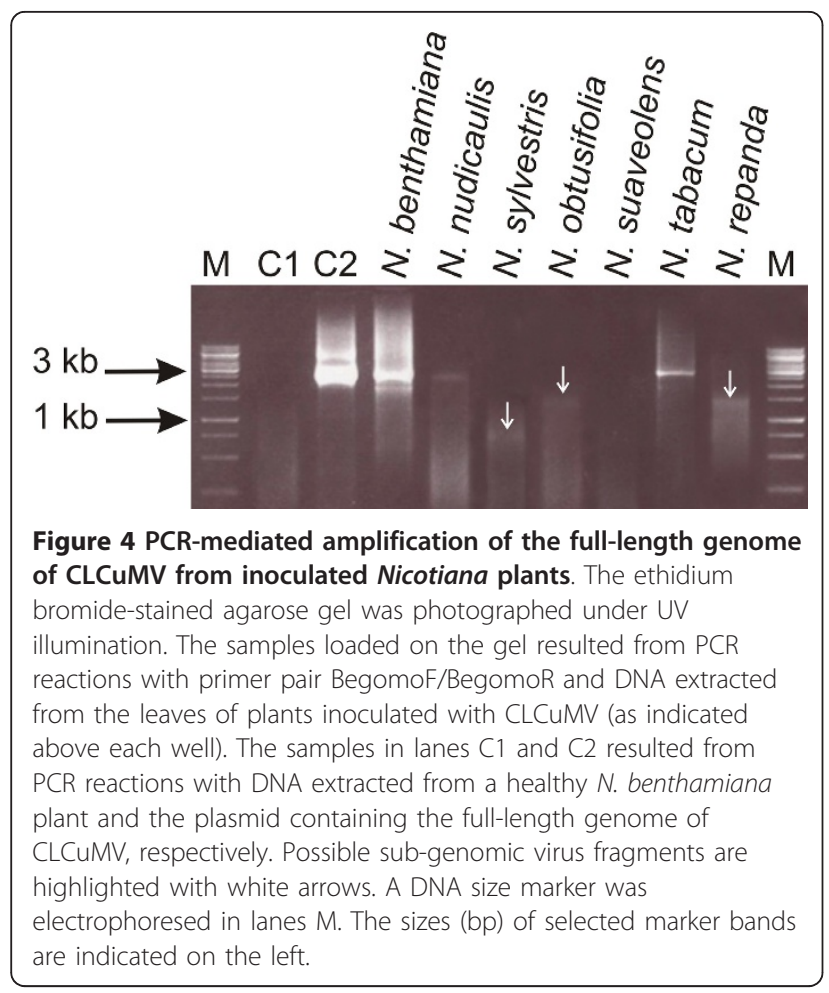

\section{PCR for RDR1m}

A natural mutation of RNA dependent RNA polymerase 1 (RDR1m), an important component of RNA silencing pathways in plants, has been identified in N. benthamiana and is believed to be responsible for the enhanced susceptibility of this species to numerous viruses, including geminiviruses [15]. The mutation of RDR1 in $N$. benthamiana is due to a $72 \mathrm{bp}$ insertion in the gene. PCR mediated amplification across the insertion showed that only $N$. benthamiana contains this mutation (fragment size $\sim 341 \mathrm{bp}$ ), with all other Nicotiana spp. investigated produced a PCR product approximately the size of an RDR1 lacking the insertion ( 269bp; Figure 9).

\section{Discussion}

The data presented here show that individual Nicotiana species differ in their susceptibility to the selected monopartite and bipartite begomoviruses. A larger number of Nicotiana spp. were susceptible to ToLCNDV infection and exhibited symptoms of infection. Three out of seven species were identified as susceptible with the virus inducing symptoms. N. sylvestris was found to be a highly susceptible host for this virus, suggesting that this species might be used as an experimental plant for this virus. The susceptibility of $N$. sylvestris (diploid species) to ToLCNDV and resistance response of $N$. obtusifolia (diploid species) to both viruses indicates that there is no clear relationship between ploidy level

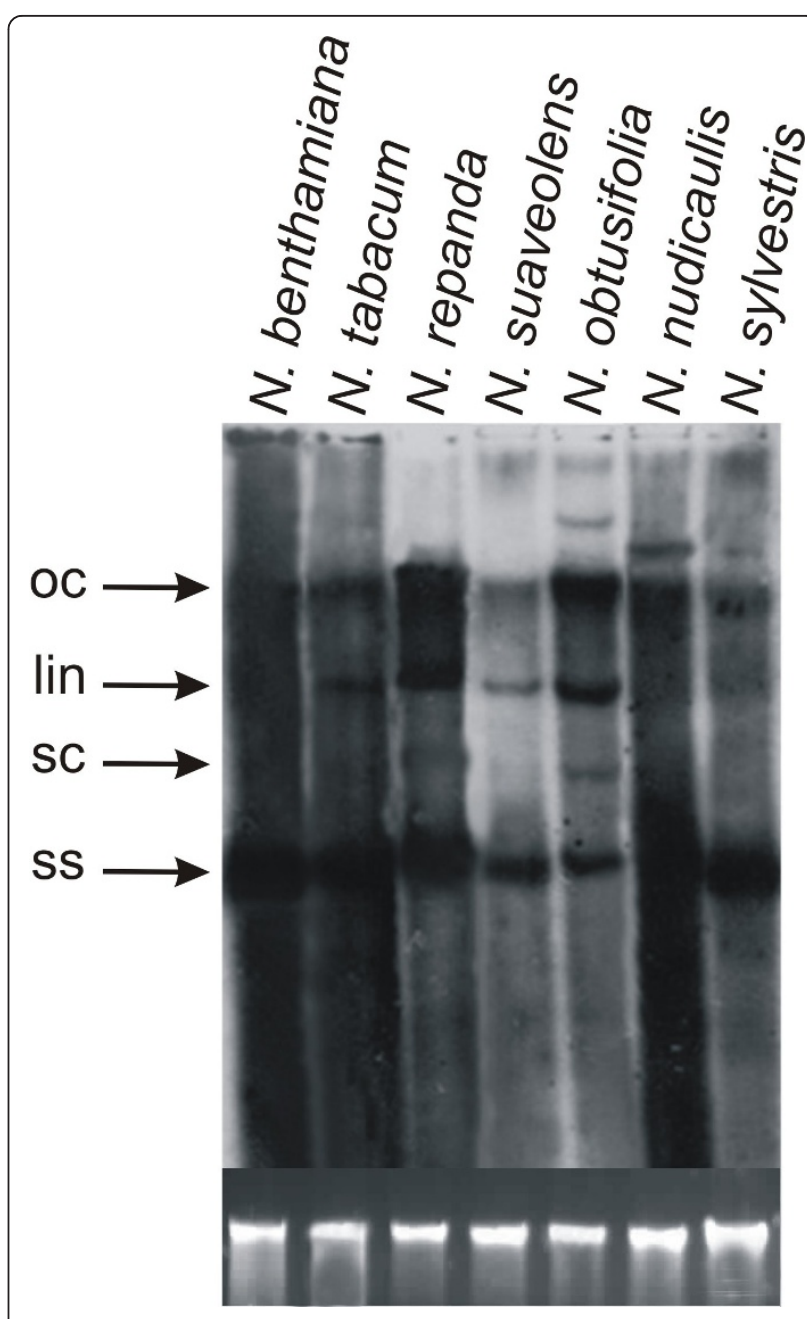

Figure 5 Southern blot detection of CLCuMV in the inoculated tissues of Nicotiana plants. The DNA samples loaded on the gel were extracted from leaves of plants (as indicated above each well) inoculated with CLCUMV. The leaves sampled were those inoculated with CLCuMV and were sampled at $25 \mathrm{dpi}$. An approximately equal amount of DNA $(10 \mu \mathrm{g})$ was loaded in each case. The blot was probed with DIG-labeled CLCuMV fragment. The positions of replicative forms of viral DNA are indicated as open circular (Oc), linear (lin), super coiled (sc) and single stranded (ss). A photograph of the genomic DNA bands on the ethidium bromide stained agarose gel to confirm equal loading is shown at the base.

and susceptibility. $N$. suaveolens, a tetraploid in section Suaveolentes appears to be resistant to both viruses.

Monopartite begomoviruses tend to be limited to tissues immediately surrounding the phloem, whereas many bipartite begomoviruses may also infect additional tissues. This is attributed to the more efficient virus movement proteins encoded by the DNA B component of bipartite viruses [16]. This more efficient virus spread in plants may explain the wider host range of ToLCNDV in Nicotiana spp. identified here in comparison to CLCuMV. Some strains of ToLCNDV are 

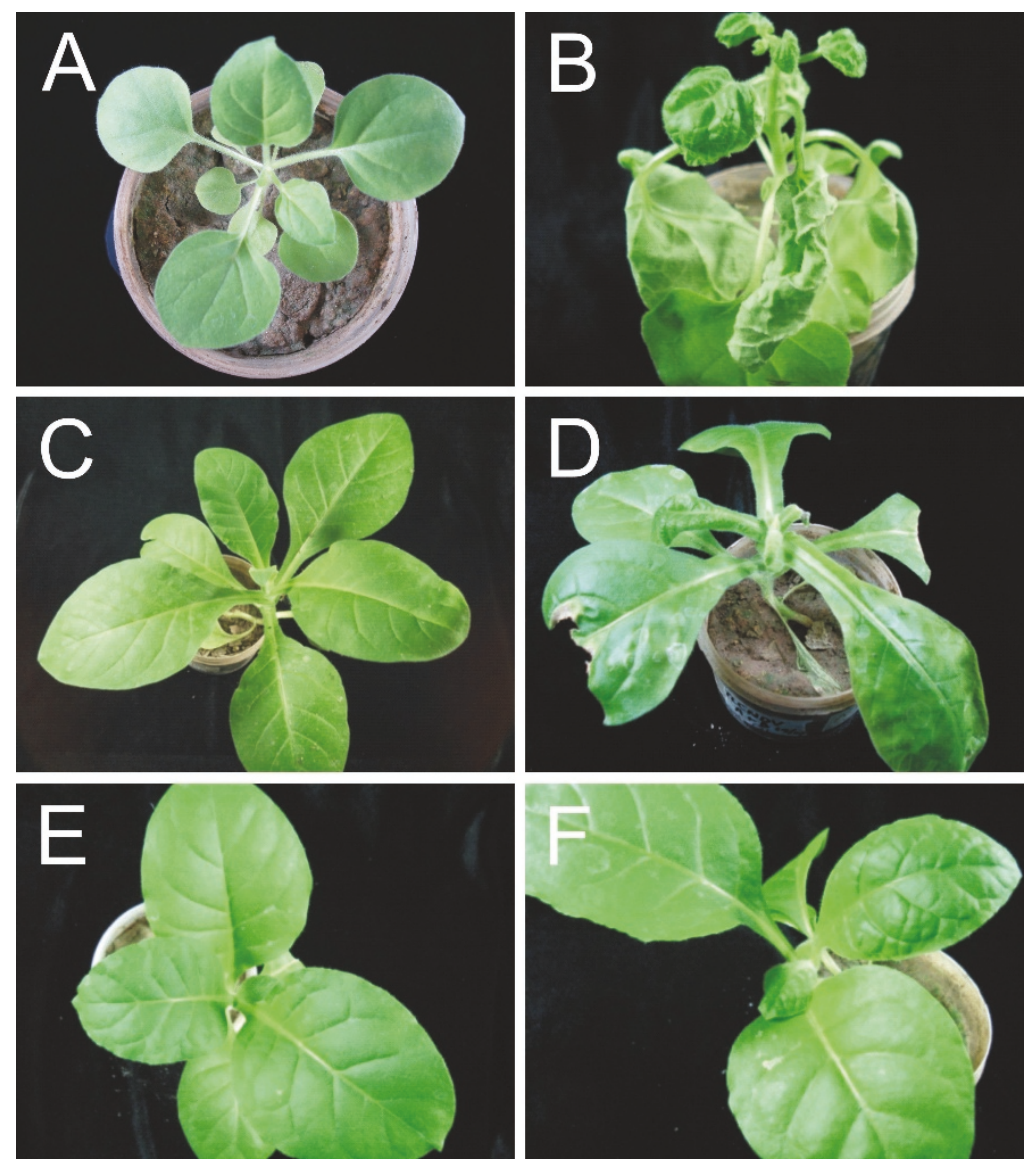

Figure 6 Symptoms exhibited by three Nicotiana species infected with ToLCNDV. Photographs of healthy N. benthamiana plant (A), N sylvestris (C) and N. tabacum (E) as well as N. benthamiana plant (B), N. sylvestris (D) and N. tabacum (F) plants infected with ToLCNDV. Pictures were taken at $21 \mathrm{dpi}$.

mechanically transmissible, indicating that the virus is able to efficiently move from inoculated (epidermal) cells to the phloem to spread throughout the plant. Biolistic inoculation is always less efficient for CLCuMV than for ToLCNDV, which is again attributed to the inability of CLCuMV to establish infection unless introduced into phloem associated cells [13].

The ability of CLCuMV to systemically infect N. tabacum without causing symptoms is of interest and suggests that the virus is either unable to invade cells that are involved in symptoms or is unable to interact with factors involved in inducing symptoms. In many cases these factors are believed to be involved in the miRNA pathway, which is affected by virus pathogenicity determinants [17].

Detectable levels of defective genomic DNAs (so called defective interfering DNAs which are less than genome length) were produced in some species ( $N$. benthamiana, N. sylvestris, N. repanda and N. obtusifolia) upon CLCuMV infection, suggesting that the virus is not well adapted to these species leading to errors in replication. Various hypotheses have been put forward regarding the mechanism(s) of production of defective geminiviral DNAs [18]. These might be produced by "jumping" of the DNA polymerase during the conversion of ssDNA to dsDNA, or during rolling circle replication of ssDNA due to the recognition of pseudo-origins of replication. Lee et al. [19] found that a large amount of sub-genomic viral DNAs were produced in an Arabidopsis thaliana ecotype (Pr-0) susceptible to Beet severe curly top virus (a geminivirus of the genus Curtovirus) but resistant to Beet curly top virus (a related curtovirus), suggesting that the host's resistance status may play a part in the production of defective DNAs. CLCuMV is a virus that is adapted to infect plants of the family Malvaceae. It is thus possible that CLCuMV is not well adapted to Nicotiana spp. and is thus not able to efficiently overcome host defenses, leading, by unknown mechanisms, to the production of defective DNAs. Alternatively, MacDowell et al. [20] suggested high levels of virus replication may be responsible for high levels of defective DNAs due to enhanced intramolecular recombination. This is consistent with our 




observation of the occurrence of sub-genomic, defective CLCUMV DNAs in N. benthamiana - a species in which virus replication is high.

$N$. benthamiana belongs to the section Suaveolentes of the genus Nicotiana. All polyploid Nicotiana outside this section are $2 n=4 x=48$. However, for polyploid section Suaveolentes chromosome numbers vary between species $(2 \mathrm{n}=4 \mathrm{x}=32$ to 48$)$ [21]. N. sylvestris is considered to be the most closely related extant species to the maternal progenitor of section Suaveolentes [22]. PCR result showed that the mutation in RDR1 is absent in N. sylvestris, which indicates either that the mutation is carried by the unknown paternal progenitor, or that the locus has been deleted subsequent to polyploidisation. With the exception of $N$. benthamiana, all other species assessed were either not susceptible to CLCuMV or supported asymptomatic infection. This may suggest that RDR1 is important in resisting symptomatic infection by this virus species.

The work presented here will pave the way to a more detailed analysis of the susceptibility of Nicotiana spp. to determine which host-encoded factors mediate resistance, for example by silencing RDR1 in Nicotiana spp. This information will be invaluable in future efforts to engineer virus resistance in crop plants.

\section{Conclusions}

The results presented here show that there is no clear relationship between begomovirus susceptibility/resistance

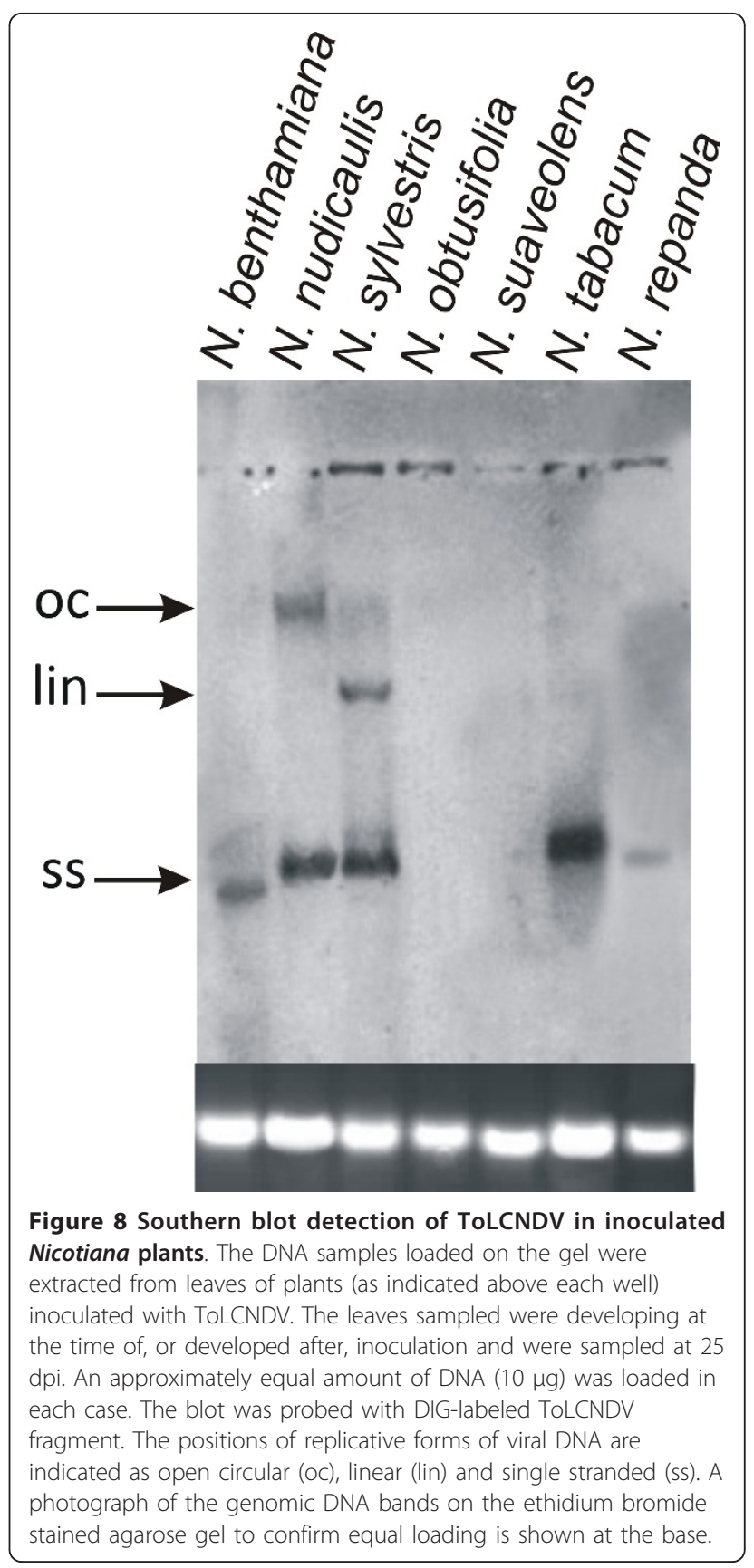

and the ploidy level of Nicotiana spp. This suggests that other factors, such as the presence of a fully functional RNA silencing response plays a part in this. For CLCuMV, lack of infectivity of a number of Nicotiana species is due to impaired movement from the site of inoculation, rather than impaired DNA replication, suggesting that these species are able to contain the virus at the initial site of entry. The insertion mutation of RDR1 was shown to be present in only $N$. benthamiana suggesting that, as first suggested by Yang et al. [15], the susceptibility of this species may be due to an impaired RNA silencing response. Defective 


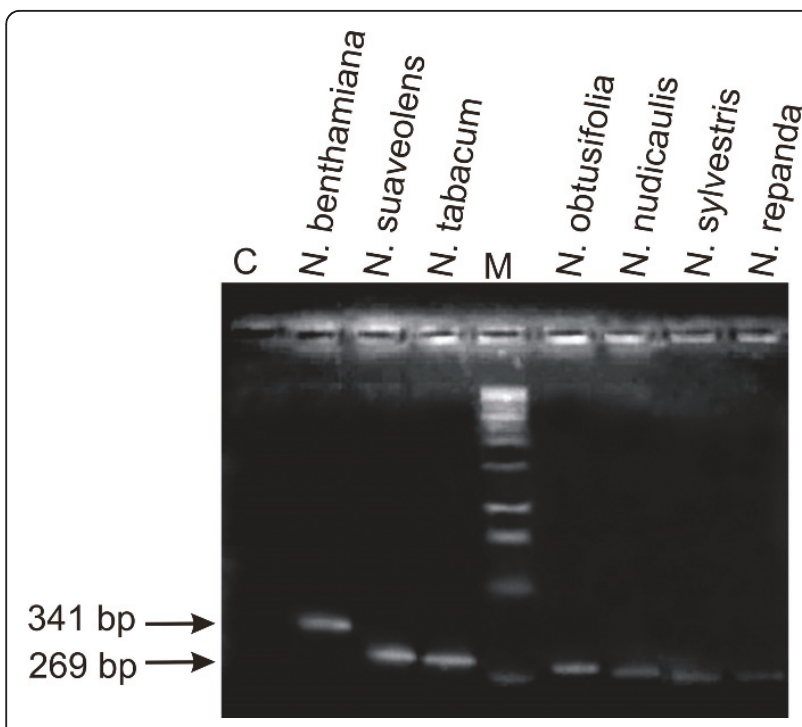

Figure 9 Identification of mutated RDR1 in Nicotiana species. Shown is an ethidium bromide-stained agarose gel photographed under UV illumination. Samples loaded resulted from PCR reactions using primer pair RDRf/RDRr and DNA extracted from leaves of the Nicotiana species. The sample in lane $C$ resulted from a PCR reaction with primers RDRf/RDRr but lacking template DNA. A DNA size marker was electrophoresed in lane M. The sizes (bp) of selected marker bands are indicated on the left.

viral DNAs were observed in both resistant and susceptible Nicotiana spp. indicating that their production is not exclusive characteristic of resistant plants.

\section{Materials and methods \\ Origin of Nicotiana seed}

Seed of Nicotiana species were kindly provided by Prof. Andrew Leitch, Queen Mary, University of London, UK and sown in pots in an insect-free containment glasshouse.

\section{Inoculation of plants with CLCUMV and ToLCNDV}

Infectious clones of CLCuMV and ToLCNDV were transformed in competent cells of Agrobacterium tumefaciens strain GV3101 and inoculum was prepared for infectivity analysis. 1.5 to $2 \mathrm{ml}$ inoculum having O.D. value of 1 was injected in two to three leaves per plant using a syringe. Four plants of each species were used for each treatment. Plants were kept in a containment glasshouse at $25-28^{\circ} \mathrm{C}$.

\section{Extraction of total nucleic acids from plants and PCR}

Total genomic DNA was extracted from leaf samples using the CTAB DNA method [23]. Genomic DNA was quantified by spectrophotometry and dilutions were made for PCR reaction to detect the virus.
Table 3 Oligonucleotide primers used in this study

\begin{tabular}{ccc}
\hline Primer & Sequence & $\begin{array}{c}\text { Predicted } \\
\text { size of } \\
\text { a plification } \\
\text { product } \\
\text { base pairs) }\end{array}$ \\
\hline RDRf & CGAGCCAGTTGCGGGATAATTC & 269,341 \\
RDRr & GAGCAAAGTCAGCAGATATT \\
CLCV1 & CCGTGCTGCTGCCCCCATTGTCCGCGTCAC & 1102 \\
CLCV2 & CTGCCACAACCATGGATTCACGCACAGGG & \\
PK3AV2F & AAATATCGATATGTGGGATCCACTATTAAACG & 311 \\
PK3AV2R & TCTGGTCGACCTATACATGGGCCTGTTGT & \\
BegomoF & ACGCGTGCCGTGYTGCTGCCCCATTGTCC & $\sim 2800$ \\
BegomoR & ACGCGTATGGGCTGYGGAGTTSASACG & \\
ToLCNDVV2F & GTCGACAAACATGTGGGATCCATTATTGC & 352 \\
ToLCNDV2R & ATCGATCTTCTATACATTCTGTACATTC & \\
TLCNDV1 & GCAGATATCATCATTCAACGC & 642 \\
TLCNDV2 & CATACTTGCCGGCCTCTTGTG & \\
\hline
\end{tabular}

\section{Detection of viral DNA in plants by Southern blot hybridization}

Virus replication in inoculated and systemic (leaves developing at the time of, or subsequent to, inoculation) leaves was assessed by Southern blot hybridization. A $1.1 \mathrm{~kb}$ PCR fragment amplified using primers CLCV1 and CLCV2 and labeled with DIG using a PCR DIG Probe Synthesis Kit (Roche, Germany) was used as probe to detect CLCuMV. ToLCNDV was detected by using a PCR-derived DNA A fragment of $642 \mathrm{bp}$, produced with primers TLCNDV1 and TLCNDV2. The sequences of primers used are given in Table 3. Primers RDRf and RDRr were designed based upon the sequence of $N$. benthamiana RDR1m available in the nucleotide sequence databases [15].

\begin{abstract}
Acknowledgements
SA was supported by the Higher Education Commission (HEC, Pakistan) under the 'Indigenous 5000 Fellowship Scheme'. RWB was supported by the HEC under the 'Foreign Faculty Hiring Scheme'. The authors would like to thank Prof. Andrew Leitch and Elizabeth Mccarthy (Cytogenetics Research Laboratory, Queen Mary, University of London) for providing seed of Nicotiana species and hosting SA for a study visit funded by the HEC under the "International Research Support Initiative Programme".
\end{abstract}

Authors' contributions

SA performed the experiments and prepared manuscript. SM provided overall directions regarding the designing of all experiments, writing and supervised the work. RWB was involved in critical review of the work and writing the manuscript. The final manuscript was read and approved by all authors.

Competing interests

The authors declare that they have no competing interests.

Received: 13 April 2011 Accepted: 19 October 2011

Published: 19 October 2011 


\section{References}

1. Clarkson JJ, Knapp S, Garcia VF, Olmstead RG, Leitch AR, Chase MW: Phylogenetic relationships in Nicotiana (Solanaceae) inferred from multiple plastid DNA regions. Mol Phylogenet Evol 2004, 33:75-90.

2. Goodin MM, Zaitlin D, Naidu RA, Lommel SA: Nicotiana benthamiana: its history and future as a model for plant-pathogen interactions. Mol Plant Microbe Interact 2008, 21:1015-1026.

3. Stanley J, Bisaro DM, Briddon RW, Brown JK, Fauquet CM, Harrison BD, Rybicki EP, Stenger DC: Geminiviridae. In Virus Taxonomy, VIIIth Report of the ICTV. Edited by: Fauquet CM, Mayo MA, Maniloff J, Desselberger U, Ball LA. London: Elsevier/Academic Press; 2005:301-326.

4. Briddon RW, Stanley J: Sub-viral agents associated with plant-infecting single-stranded DNA viruses. Virology 2006, 344:198-210.

5. Seal SE, van den Bosch F, Jeger MJ: Factors Influencing begomovirus evolution and their increasing global significance: implications for sustainable control. Crit Rev Plant Sci 2006, 25:23-46.

6. Roth BM, Pruss GJ, Vance VB: Plant viral suppressors of RNA silencing. Virus Res 2004, 102:97-108.

7. Voinnet $\mathrm{O}$ : Induction and suppression of RNA silencing: insights from viral infections. Nature Genet 2005, 6:206-221.

8. Lecellier $\mathrm{CH}$, Voinnet O: RNA silencing: no mercy for viruses? Immunol Rev 2004, 198:285-303

9. Sharma P, Ikegami M: RNA-silencing suppressors of geminiviruses. J Gen Plant Pathol 2008, 74:189-202.

10. Cui X, Li G, Wang D, Hu D, Zhou X: A begomovirus DNA $\beta$-encoded protein binds DNA, functions as a suppressor of RNA silencing, and targets the cell nucleus. J Virol 2005, 79:10764-10775.

11. Saunders K, Norman A, Gucciardo S, Stanley J: The DNA $\beta$ satellite component associated with ageratum yellow vein disease encodes an essential pathogenicity protein ( $\beta C 1)$. Virology 2004, 324:37-47.

12. Chapman EJ, Prokhnevsky Al, Gopinath K, Dolja W, Carrington JC: Viral RNA silencing suppressors inhibit the microRNA pathway at an intermediate step. Genes Dev 2004, 18:1179-1186.

13. Mansoor S, Briddon RW, Bull SE, Bedford ID, Bashir A, Hussain M, Saeed M, Zafar MY, Malik KA, Fauquet C, Markham PG: Cotton leaf curl disease is associated with multiple monopartite begomoviruses supported by single DNA $\beta$. Arch Virol 2003, 148:1969-1986.

14. Padidam M, Beachy RN, Fauquet CM: Tomato leaf curl geminivirus from India has a bipartite genome and coat protein is not essential for infectivity. J Gen Virol 1995, 76:25-35.

15. Yang SJ, Carter SA, Cole AB, Cheng NH, Nelson RS: A natural variant of a host RNA-dependent RNA polymerase is associated with increased susceptibility to viruses by Nicotiana benthamiana. Proc Natl Acad Sci, USA 2004, 101:6297-6302.

16. Rojas MR, Jiang $H$, Salati $R$, Xoconostle-Cazares B, Sudarshana MR, Lucas WJ, Gilbertson RL: Functional analysis of proteins involved in movement of the monopartite begomovirus, Tomato yellow leaf curl virus. Virology 2001, 291:110-125

17. Amin I, Patil BL, Briddon RW, Mansoor S, Fauquet CM: A common set of developmental miRNAs are upregulated in Nicotiana benthamiana by diverse begomoviruses. Virol J 2011, 8:143.

18. Patil BL, Dasgupta I: Defective interfering DNAs of plant viruses. Crit Rev Plant Sci 2006, 25:47-64.

19. Lee S, Stenger DC, Bisaro DM, Davis KR: Identification of loci in Arabidopsis that confer resistance to geminivirus infection. Plant J 1994, 6:525-535.

20. MacDowell SW, Coutts RHA, Buck KW: Molecular characterization of subgenomic single-stranded and double-stranded DNA forms isolated from plants infected with tomato golden mosaic virus. Nucleic Acids Res 1986, 14:7967-7984.

21. Goodspeed TH, Wheeler HM, Hutchison PC: The genus Nicotiana - Origins, relationships, and evolution of its species in the light of their distribution, morphology, and cytogenetics. Chronica Botanica Co. Waltham, Massachussets, USA 1954.

22. Clarkson JJ, Kelly LJ, Leitch AR, Knapp S, Chase MW: Nuclear glutamine synthetase evolution in Nicotiana: phylogenetics and the origins of allotetraploid and homoploid (diploid) hybrids. Mol Phylogenet Evol 2010, 55:99-112.

23. Doyle JJ, Doyle JL: Isolation of plant DNA from fresh tissue. Focus 1990, 12:13-15.
doi:10.1186/1743-422X-8-475

Cite this article as: Akhtar et al:: Reactions of Nicotiana species to inoculation with monopartite and bipartite begomoviruses. Virology Journal 2011 8:475.

\section{Submit your next manuscript to BioMed Central and take full advantage of:}

- Convenient online submission

- Thorough peer review

- No space constraints or color figure charges

- Immediate publication on acceptance

- Inclusion in PubMed, CAS, Scopus and Google Scholar

- Research which is freely available for redistribution 